\title{
The teaching approach on communicative skills in different teaching methodologies
}

\author{
O olhar docente sobre as habilidades comunicativas em diferentes metodologias de ensino
}

La mirada docente sobre las habilidades comunicativas en diferentes metodologías de enseñanza

\section{Karime Rodrigues Emilio de Oliveira', Monica Martins Trovo", Amanda Creste Martins da Costa Ribeiro Risso"I', Eliana Mara Braga'}

' Universidade Estadual Paulista Júlio de Mesquita Filho, Department of Nursing. Botucatu, São Paulo, Brazil. " Universidade São Judas Tadeu, School of Biological and Health Sciences. São Paulo, Brazil.

III Irmandade de Santa Casa de Misericórdia de São Carlos. São Carlos, São Paulo, Brazil.

\section{How to cite this article:}

Oliveira KRE, Trovo MM, Risso ACMCR, Braga EM. The teaching approach on communicative skills in different teaching methodologies. Rev Bras Enferm [Internet]. 2018;71(5):2447-53. DOI: http://dx.doi.org/10.1590/0034-7167-2017-0728

Submission: 10-22-2017 Approval: 05-17-2018

\section{ABSTRACT}

Objective: to understand, from the perspective of professors, which are the facilities and difficulties in the development of communication skills in nursing undergraduates who experiment different teaching-learning methodologies. Method: qualitative research performed with 30 nursing professors from two public education institutions. The data was collected by semi-structured individual interview with guiding questions. We used Bardin's content analysis for the data processing and analysis. Results: the development of communication skills is influenced by factors such as the experience of practical activities, students' individual characteristics, use of active methodologies, access to the mass media, relationship of proximity between student and professor, and knowledge of theoretical concepts of communication and nursing. Final considerations: there is similarity between the influential factors, however, the use of active methodologies seems to favor the development of communication skills.

Descriptors: Communication; Education, Nursing; Aptitude; Faculty, Nursing; Students, Nursing.

RESUMO

Objetivo: compreender, sob a perspectiva de docentes, quais são as facilidades e dificuldades no desenvolvimento de habilidades comunicativas em graduandos de enfermagem que vivenciam diferentes metodologias de ensino-aprendizagem. Método: pesquisa qualitativa realizada com 30 docentes enfermeiros de duas instituições públicas de ensino. A coleta de dados foi realizada por entrevista semiestruturada individual com questões norteadoras. Para o tratamento e análise dos dados, utilizouse a análise de conteúdo segundo Bardin. Resultados: o desenvolvimento de habilidades comunicativas tem a influência de fatores como a vivência das atividades práticas, características individuais estudantis, utilização de metodologias ativas, acesso aos meios de comunicação de massa, relação de proximidade entre professor-aluno e conhecimento dos conceitos teóricos de comunicação e de enfermagem. Considerações finais: há semelhança entre os fatores influentes, no entanto o uso das metodologias ativas parece favorecer o desenvolvimento de habilidades em comunicação.

Descritores: Comunicação; Educação em Enfermagem; Aptidão; Docentes de Enfermagem; Estudantes de Enfermagem.

\section{RESUMEN}

Objetivo: comprender, bajo la perspectiva de docentes, cuáles son las facilidades y dificultades en el desarrollo de habilidades comunicativas en estudiantes de enfermería que experimentan diferentes metodologías de enseñanza-aprendizaje. Método: investigación cualitativa realizada con 30 docentes enfermeros de dos instituciones públicas de enseñanza. Se realizó la recolección de datos por entrevista semiestructurada individual con cuestiones orientadoras. Para el tratamiento y análisis de los datos, se utilizó el análisis de contenido según Bardin. Resultados: el desarrollo de habilidades comunicativas tiene la influencia de factores como la vivencia de las actividades prácticas, características individuales estudiantiles, utilización de metodologías activas, acceso a los medios de comunicación de masa, relación de proximidad entre profesor-alumno y conocimiento de los 
conceptos teóricos de comunicación y de enfermería. Consideraciones finales: hay similitud entre los factores influyentes, sin embargo el uso de las metodologías activas parece favorecer el desarrollo de habilidades en comunicación.

Descriptores: Comunicación; Educación en Enfermería; Aptitud; Docentes de Enfermería; Estudiantes de Enfermería.

\section{CORRESPNDING AUTHOR Karime Rodrigues Emilio de Oliveira E-mail: karime.rodrigues@bol.com.br}

\section{INTRODUCTION}

Nursing brings the care in its essence, and interpersonal relationships established with patients, families, community and the multidisciplinary health team are the base of the nurse's work.

The care is expressed in the interpersonal relations and constitutes means of communication since it involves the contact among human beings through speech, facial and body expressions, hearing, smell, touch, and intervening in the body of others ${ }^{(1)}$. Therefore, communication is present in every moment of the nurse's practice, constituting one of the bases of nursing care ${ }^{(2)}$.

The main function of communication in the assistance is to establish a significant relationship with the patient, because it is through this relationship that the nurse will care for the patient ${ }^{(2)}$.

A study that considered the opinion of nursing undergraduates on the professional skills required for nurses demonstrated that the communication and the establishment of an effective interpersonal relationship are fundamental to the performance of future nurses ${ }^{(3)}$.

Therefore, it is necessary that the nursing student invest in developing communication skills in order to establish an adequate care plan that is coherent with the patients ${ }^{\prime}$ needs ${ }^{(1)}$, knowing what and how to ask questions to investigate demands and needs of patients, how to listen in an active and welcoming way, and how to guide, using clarity and assertiveness.

As we can see, the communication skill is a fundamental condition to the nurse's practice. Considering that ability constitutes a series of mental procedures the individual triggers to solve an actual situation in which there is a need to make decisions $^{(4)}$, its development and improvement should happen from the beginning of the academic qualification, since the undergraduate students must understand early on their formation the importance of building a significant interpersonal relationship and the adequate use of communication in the context of care.

The teaching of interpersonal communication in nursing has the basic premise of following the communicative progression of the student concomitantly to the process of teaching-learning. Monitoring the construction of this skill is responsibility and competence of the professor ${ }^{(5)}$.

Therefore, the professors' performance becomes significant in the teaching-learning process of communication skills, and the professor's verbal and nonverbal communicative behaviors can motivate or discourage the students' learning, that is, the professor's way of acting influences learning ${ }^{(5-6)}$.

\section{OBJECTIVE}

To understand, from the perspective of professors, which are the facilities and difficulties in the development of communication skills in nursing undergraduates who experiment different teaching-learning methodologies.

\section{METHOD}

\section{Ethical aspects}

This study was carried out according to Resolution 466/12 of the National Health Council (CNS) and the National Commission on Ethics in Research (Conep) ${ }^{(7)}$. The project was initially submitted to the Research Ethics Committee (CEP) of Institution 1 and was approved by it. Afterwards, the research project was also submitted to and approved by the CEP of Institution 2 .

To the individuals who, after explanation of the study by the researcher, agreed to participate in the research, the signing of the Informed Consent Form (TCLE) was requested in two copies, one for the participants and another for the researcher. The freedom of participation was ensured, as well as the participant's right to leave at any moment, without any prejudice or embarrassment.

\section{Type of study}

This is a qualitative research, as this choice for the development of the study topic is capable of incorporating meaning and intentionality as inherent to acts, relations and social structures, the latter being taken both in its advent and in its transformation as significant human constructions ${ }^{(8)}$.

\section{Methodological procedures}

The data was collected from February to October 2014 in two public institutions of higher education in nursing, located in the state of São Paulo, Brazil, hereby named "Institution 1" and "Institution 2".

\section{Study scenario}

The Institution 1 was selected because it adopts a traditional teaching methodology, although it also used other teachinglearning methods, such as students presenting and elaborating seminars. The Institution 2 was selected because it only adopts active teaching-learning methodologies.

In Institution 1, the undergraduate studies prevocational disciplines in the first year. These are taught through theoretical and practical lessons. From the second year on, the vocational disciplines begin, with theoretical, theoretical-practical and practical activities $^{(9)}$.

The Institution 2, by using active teaching-learning methodologies, opts for the application of learning based in problems and questioning ${ }^{(10)}$.

Learning based in problems is a learning method in which the students face a problem elaborated by a group of professionals. From this problem, they start an student- centered investigation process to define the problem and, elaborate hypothesis to explain them, in addition to exploring the students' previous knowledge that are relevant to the subject. The key element is the formulation of learning questions, which can be answered 
through systematic and self-directed investigation, being essential to the students' active discussion process ${ }^{(10-11)}$.

The questioning is based on the critical pedagogy of the education field, which rely on Paulo Freire's pedagogical assumptions. This methodology is supported by the dialectical method, in which the praxis will direct the learning movement, with the transforming action-reflection-action relation being the basic axis of the learning orientation. Thus, learning happens through the act of reflection on the professional practice, in which both students and professors are included ${ }^{(10)}$.

\section{Data source}

All the nursing professors with at least a doctorate degree from both educational institutions were invited to participate in the research. There are 54 professors; 24 from Institution 1, and 30 from Institution 2.

A total of 30 professors participated in this study, 11 from Institution 1 and 19 from Institution 2, using the criterium of theoretical saturation. The researcher contacted them by e-mail and explained the study objectives. After acceptance, the interviews were scheduled.

\section{Data collection and organization}

To achieve the proposed objective, firstly, participants' characterization was performed through the filling - by the researcher - of a printed form containing variables of age, sex, time since graduation and teaching experience. Then, a semi-structured individual interview was performed with the following guiding questions: 1) What are the facilities you notice in the communication skills of nursing students? 2) What are the difficulties that you notice in the communication skills of nursing students?

These interviews were recorded in a digital audio device, and had an average duration of 30 minutes and were subsequently transcribed, respecting the speech colloquiality.

\section{Data analysis}

We used the content analysis proposed by Bardin ${ }^{(12)}$ as a methodological referential. This methodology is defined as a set of communication analysis techniques. Through systematic and objective procedures for describing the content of messages, they aim at obtaining quantitative or non-quantitative indicators that allow the inference of knowledge regarding conditions of production/reception (inferred variables) of those messages.

There are three stages that characterize it: the pre-analysis, the exploration of the material, and the processing of the results. In the pre-analysis, we transcribed the interview entirely and a free-floating reading of texts, making exhaustive contact with the material ${ }^{(12)}$.

In the following phase of analytical description, we made cuts and the choice of registration units, choosing and codifying them through convergence with the phenomenon. Thus, we classified the thematic units based in a group of elements, a process called semantic categorization ${ }^{(12)}$.

In the results processing, we could understand from the perspective of nursing professors how the development of communicative skills occurs in the undergraduates of institutions that use different teaching-learning methodologies.

The participants' speeches in this study will be identified by letters " $\mathrm{P}$ ", corresponding to the participant and his/her number, and "I", indicating the institution. For example, "P1, I1" or "P1, I2".

\section{RESULTS}

Regarding the characterization of the participants from Institution 1 , a total of 11 professors participated. Of these, all were women ageing from 50 to 59 years; teaching practice time from 20 to 29 years; and time since the graduation in nursing from 30 to 39 years.

From Institution 2, 19 professors participated in the study, and all of them were also women. The prevalent age group was from 50 to 59 years, and the time of teaching practice was from 20 to 29 years, similar to Institution 1 . As for the time since nursing graduation, the prevalence was from 20 to 29 years. Therefore, 30 professors participated in this study.

Because it is a qualitative research, the interviews' speech was the main source of information to the analysis. Given this context, the topic, categories and results found are described as follows.

\section{Topic - Factors that influence on the development of com- munication skills in nursing students}

\section{Category 1 - Practical activities promote acquisition of communication skills}

For the professors, the scenario of practical activities is an essential and vital factor to the development of communication skills in students.

From the perspective of the interviewed, this scenario becomes rich as it allows the student to really exercise his/her communication, develop professional autonomy and attitudes to establish a link with patients, families and health teams.

The practice also allows students' weaknesses and potentials to become more transparent. By experiencing the context of the health environment, the student gets to know him/herself, as well as recognizes his/her possible difficulties, whether in cognitive learning or in interpersonal relationships.

From the professors' speeches, the greater the experience in practical scenarios, the greater the probability that students will gain self-confidence to establish effective interpersonal relationships in health environments.

I think that what helps them to acquire this skill is to put themselves to the test, to develop some activity in an internship when they have to communicate [...] they need to exercise it and exercise it several times. (P11, I1)

I think that these findings, posture, way of talking, nonverbal communication, happen when they are with the patient or in practice. Practice is the base of everything. In practice, their frailties will be transparent. (P23, I2)

\section{Category 2 - The individual characteristics of students}

The professors of both education institutions expressively attributed the students' facilities and difficulties of communication to their individual characteristics.

The facility or difficulty was mainly due to the school and family education, and the communication stimulus that students had during their child and adolescent development.

What makes it easy are the student that manage to develop themselves, either by their own profile or by life experiences, 
and this comes from their previous experience, or if they have already put it in practice in other moments. (P11, I1)

Shyness is a difficulty. The shy people is the biggest problem. They will have more measured attitudes, difficulty to relate, to integrate into the team... they can't function in public, even in small groups. (P5, I1)

The facility is a very personal issue. Some have it, come with it, and others, even if we provide this, it is hard for them to be exposed, because it is a behavioral issue [...] but I think it is a skill that must be developed. Few have it naturally. (P16, 12)

Another difficulty is the one that cannot find space to talk [...] they studied, but are unable to expose themselves. (P12, I2)

\section{Category 3 - The use of active teaching-learning methodologies}

The use of active teaching-learning methodologies is a factor that provides the development of communication skills in students, from the perspective of professors from Institution 2.

The participants stated that the factors which deserved to be highlighted in the development of communication skills within the active methodologies are: problem-based learning, questioning, organizing the teaching-learning process in small groups and the scenario of simulation of real experiences in healthcare environments.

For professors from Institution 2, both problem-based learning and questioning encourage the students to express themselves verbally. These are student-centered teaching-learning processes, not a teacher-centered approach. In these methodologies, the students should verbally share their previous and new knowledge with a group of classmates, being that the joint participation of all group members to build collective knowledge is part of the methodological assumption of the active methods.

The professors pointed that one of the positive aspects of using the questioning methodology to develop communication skills is that it allows the students to verbally express their experiences and observations of reality, discussing them collectively in small groups, since the teaching-learning process in this method comes from experiences and learning needs felt by the students.

The form of organization of the teaching-learning process only in small groups, which occurs in Institution 2, was widely expressed as a factor that allows the development of communication skills. According to the educators, it favors the construction of bonds between professor and student, or among students, so they fell free to express their ideas, thoughts, anxieties, facilities and difficulties of learning and communication.

Those professors explained that in small groups they can clearly detect the students that have communication difficulties of expressing themselves verbally or that have an inadequate behavior, such as the absence of professional posture, difficulties to interpret texts and to express what was understood, and when the nonverbal communication is not coherent with the verbal one.

Another aspect regarding small groups was that this form of learning organization allows the identification of students that have communicative facilities from the point of view of verbal expression. To those professors, the students that have this facility need to adapt to the context as well as those who do not have it. They emphasized that the effective functioning of the groups, from the pedagogical point of view, only occurs when all students, with no exception, express their thoughts, comprehension of the topics studied and, especially, when they learn to listen to others.

The simulation scenario was also considered a good technique to work on those skills. When this is provided to the nursing students in the freshman-year, it allows the professors to early identify the students' difficulties, whether cognitive or emotional. From this, professors elaborate strategies with the students to overcome difficulties and build skills, in addition to being an exercise to the communication practice in healthcare environments.

By performing simulated situations of patient care, the professors expressed that the students get to know themselves better, that is, the weaknesses and potentials become clearer to students, since they will exercise their skills in a protected scenario. This also allows students to accept the training assessments in a calmer way.

This is part of the problem-based learning [...] all student have to expose their knowledge [...] they gradually learn how to speak at the right moment, to wait for the other, so that everybody talks, and not only one person. (P16, 12)

The questioning allows the student to better express their experiences in the group discussions because the teaching comes from what the students live. Either through a written narrative or an oral report. (P28, I2)

In the simulation scenario, somehow, this simulated actor provides that the student talks [...] and his/her frailty is more exposed. Then, it is easier to work on this, because the diagnosis is made at the beginning of the program. (P17, I2)

In small groups, the students feel some characteristics, such are shyness, difficulty to be in public [...] when you are in a large classroom, in the traditional model, you can't do it, you will identify the nonverbal of something very absurd. (P27, I2)

In their speeches, the professors from Institution 1 did not mention to use active teaching-learning methods, confirming the traditional teaching as predominant in the course.

Category 4 - The interference of the access to mass media Another factor that interferes in the development of those skills is the access to mass media, especially the internet.

The interviewed stated that the internet access is something positive, since the students have access to knowledge from other sources, not being restricted only to books.

However, the professors highlighted and criticized the exacerbated use of social media by the students, social networks and for sharing of photos and videos, such as: Facebook, Instagram and YouTube, which are used in class, especially through cell phones, in moments intended for learning.

It is important to note that the use of cell phones by students in moments intended for the teaching-learning process was 
verbalized only by professors from Institution 1, and it was not mentioned by professors from Institution 2 .

It is worth mentioning that both education institutions pointed out how this exacerbated access to social media can interfere in interpersonal relationships in the healthcare area. They note that students are communicating and increasingly opt to interact through internet. This can hinder face-to-face interactions, since students also need to be sensitive to the correct perception and codification of nonverbal communication to demonstrate communication skills and to establish a good interpersonal relationship, which is damaged by the communication through internet.

The student is there, but he is connected to other things, like the cell phone, for example. (P2, I1)

The internet made it difficult for students to communicate [...] they communicate a lot through writing only. (P23, I2)

Category 5 - The relation of proximity of professors and students From the perspective of the interviewed, the higher the relation of proximity professor-student, the greater is the perception of students' weaknesses and potentials of communication. According to the educators, the proximity allows to know and to better understand the individualities and, with that, there is greater possibility for the professor to help in the overcoming of weaknesses.

The professors from Institution 1 emphasized that it is in the professional practice scenario, when the groups of students are smaller, that they establish a greater relation of proximity with the students, noting that the smaller the group of students under their supervision, the greater the proximity and, consequently, the perception of skills.

As for the participants from Institution 2, they valued the greater proximity they have with the students and attributed it to the organization of the teaching-learning process in small groups, comparing it to the experience of the traditional teaching. According to them, the traditional form provided less proximity between professor and student.

I can better notice the communication skill in practice, also because I am closer to my students. When I'm in a class with 30, 35 students, it is harder to notice this skill. (P11, I1)

The proximity is much greater now, with this methodology. We notice things that before, in a group with 40 students, we couldn't notice... a saddened student, that had difficulty in learning, another that had more facility. Everything was very individualistic. (P22, I2)

\section{Category 6 - The knowledge of theoretical communication and nursing concepts}

The interviewed from Institution 1 stated that they notice students that have more theoretical bases on communication can establish more effective relations in healthcare environments.

From the perspective of those from Institution 2, a factor that enables the participation of students in the discussions of small groups and gives them credibility to stablish relations in the healthcare environments is when they are strengthened from the cognitive point of view, that is, when they have theoretical background, allowed by the search for information. This, for the professors, is an opportunity to develop communication skills, as students become confident to express themselves verbally.

As they have the nurse-patient relationship course, they know it, they seek to communicate better with the user, with the patient in the internship. (P1, I1)

It is much easier for the students to speak when they have content [...] I notice they expose their ideas more easily when they have studied. When they lack content or study, it is very hard for them to enter the group discussion. (P16, I2)

\section{DISCUSSION}

A Brazilian study points out that the insertion in practice scenarios facilitates the teaching-learning process because students consider the dialogue between theory and professional practice as the most significant way of learning, being fundamental for them to visualize the applicability of what is taught in class to better understand the healthcare process ${ }^{(13)}$.

A study that analyzed the opinion of nursing students on the communicational process in healthcare environments found that the potential or weakness to communicate is related to their personality. That is, there are students in the beginning of the course that already find communication easy, and others that are at the end of the program and still have difficulties, which shows that communication is also related to people's way of behaving ${ }^{(14)}$.

Regarding the active learning methods, there is a study that assessed the use of problem-based learning in small groups, from the perspective of graduated nurses, pointing that this form of organization represents a favorable context to work on difficult aspects that students may have regarding communication, and to improve these aspects before the student is placed in contact with the patients, families and healthcare teams, corroborating the findings in this study ${ }^{(15)}$.

In addition, researchers state that in the problem-based learning the students perform their own search for knowledge in several sources, from their needs, and this favors the satisfactory elaboration of knowledge and of the student's personal development ${ }^{(16)}$.

In the questioning pedagogy, educational cycles based in the discussions of professional practice experiences which are significant to the student's life are performed, corroborating the findings in our study ${ }^{(17)}$.

Those discussions happen through dialogue, in which students must be active and seen as equals. Therefore, we observed it is a teaching method that gives the opportunity to develop communication skills, as the active discussion is necessary among the students ${ }^{(17)}$.

The simulation practices offer the student the opportunity to develop confidence to communicate, but it should be noted that sharing communication theories is not enough for the learning, and the physical application of the theory remains essential. The authors also state that this teaching strategy can provide an efficient pedagogical approach to the teaching-learning process of communication skills ${ }^{(18)}$.

Another study demonstrates that performing procedures and scenarios of assisting the patient in an environment simulated by the students encourages the learning, and they are well accepted by the students, who feel valued, motivated and active in the teaching-learning process ${ }^{(19)}$. 
A study points out that learning in group is fundamental, since it gives the students the opportunity to develop skills that are necessary to future collaborative practices in their profession, in addition to the ability to solve problems and conflicts ${ }^{(20)}$.

As for the access to mass media, $96 \%$ of a sample of 271 nursing students claimed to have access to the internet, $85 \%$ have some experience or knowledge in information technology, and $62.4 \%$ would like to use the computer as a support tool for learning, as they believe its use can offer more dynamism and complement theoretical lessons ${ }^{(21)}$.

Our study also agrees with the literature that states that activities performed in internships allow more proximity between professor and student when compared to theoretical lessons. This is considered a positive relationship, since it allows the professor to better understand the students ${ }^{(22)}$.

In addition, authors point out that activities developed in the daily life of curricular internships are more challenging to the pedagogical relationship between students and professors, as the demands come from actual and concrete needs, and it is up to the professor to promote reflections on the patient's needs ${ }^{(23)}$.

The communication must be seen as a body of knowledge that permeates the whole nursing practice, therefore, the knowledge on communication in health becomes essential to healthcare and to other nursing areas ${ }^{(2)}$.

In a study, nursing students claimed how important it is to have previous nursing knowledge to deal with patients. They say that, when they do not have previous theoretical knowledge, they feel insecure in the interactions with patients ${ }^{(14)}$.

\section{Study limitations}

The study limitations are the small number of researches on the topic of developing communication skills in higher education programs.

\section{Contributions to the field of nursing and health care}

This study brings contributions to the nursing teaching as it allows to identify potentials and weaknesses to develop communication skills in future nurses, directing to the improvement of the teaching-learning process.

\section{FINAL CONSIDERATIONS}

When we seek to understand how the development of communicative skills occurs in nursing students, we noted this is influenced by several factors, such as: experience in practical activities, their individual characteristics, the access to mass media, the relation of proximity established with the professor and the knowledge on theoretical concepts of communication and nursing. These are influencing factors, from the perspective of professors, regardless of the teaching methodology used.

However, we emphasize that the use of active methodologies was expressly pronounced by the professors of Institution 2 as a teaching method that strengthens and favors the communicative process and, consequently, the development of communication skills. Through the use of the problem-based and the questioning learning, the teaching-learning process organized in small groups and the simulation scenario of real experiences in healthcare environments, this method allows the student to have more opportunities and probability of developing such skills effectively.

To the professors from Institution 1, one of the strong points found in teaching that favors the development of those skills is the experience in practical activities. This gives the possibility of forming smaller groups of students, which provide more proximity between professors and students. In addition, there is the recognition of offering three disciplines focused on the relationship between nurses and patients, showing that this teaching method also includes strategies for the development of communication skills.

\section{REFERENCES}

1. Silva MJP. Comunicação tem remédio: a comunicação nas relações interpessoais em saúde. 8. ed. São Paulo: Loyola; 2011.

2. Stefanelli MC, Carvalho EC. A comunicação nos diferentes contextos da enfermagem. 2. ed. Barueri: Manole; 2012.

3. Leal LA, Camelo SHH, Soares MI, Santos FC, Correa R, Chaves LDP. Professional competences for nurses: the view of undergraduate nursing students. Rev Baiana Enferm[Internet]. 2016[cited 2017 Sep 3];30(3):1-12. Available from: https://portalseer.ufba.br/index. php/enfermagem/article/view/16380/pdf_67

4. Perrenoud P. 10 novas competências para ensinar. Porto Alegre: Artmed; 2000.

5. Braga EM, Silva MJP. How communication experts express communicative competence. Interface[Internet]. 2010[cited 2017 Sep 1];14(34):529-38. Available from: http://www.scielo.br/pdf/icse/v14n34/aop0910.pdf

6. Amorim RKFCC, Silva MJP. Nursing faculty's opinion on effectiveness of non-verbal communication in the classroom. Acta Paul Enferm[Internet]. 2014[cited 2017 Sep 1];27(3):194-9. Available from: http://www.scielo.br/pdf/ape/v27n3/en_1982-0194ape-027-003-0194.pdf

7. Brasil. Ministério da Saúde. Conselho Nacional de Saúde. Resolução nº 466, de 12 de dezembro de 2012. Diário Oficial da União[Internet]. 2013[cited 2017 Sep 1];12:59. Available from: http://conselho.saude.gov.br/resolucoes/2012/Reso466.pdf

8. Minayo MCS, Deslandes SF. Pesquisa social: teoria, método e criatividade. 33. ed. Petrópolis: Vozes; 2013.

9. Universidade Estadual Paulista. Faculdade de Medicina de Botucatu. Conselho de curso de graduação em enfermagem. Projeto político-pedagógico do curso de graduação em enfermagem da Faculdade de Medicina de Botucatu: reestruturação. Botucatu: Faculdade de Medicina de Botucatu; 2003.

10. Faculdade de Medicina de Marília. Projeto pedagógico do curso de enfermagem 2008. Marília: Faculdade de Medicina de Marília; 2008. 
11. Campos LRG, Ribeiro MRR, Depes VBS. Autonomy of nursing undergraduate student in the (re)construction of knowledge mediated by problem-based learning. Rev Bras Enferm[Internet]. 2014[cited 2017 Sep 3];67(5):818-24. Available from: http://www.scielo. br/pdf/reben/v67n5/0034-7167-reben-67-05-0818.pdf

12. Bardin L. Análise de conteúdo. 5. ed. São Paulo: Edições 70; 2011.

13. Canever BP, Prado ML, Backes VMS, Gomes DC. Production of knowledge about the training of nurses in Latin America. Rev Gaúcha Enferm[Internet]. 2012[cited 2017 Sep 3];33(4):211-20. Available from: http://www.scielo.br/pdf/rgenf/v33n4/en_26.pdf

14. Oliveira KRE, Braga EM. The development of communication skills and the teacher's performance in the nursing student's perspective. Rev Esc Enferm USP[Internet]. 2016[cited 2017 Sep 3];50(Spec No):31-7. Available from: http://www.scielo.br/pdf/ reeusp/v50nspe/0080-6234-reeusp-50-esp-0032.pdf

15. Giribet MC, Moya JLM. Strengths and weaknesses of Problem Based Learning from the professional perspective of registered nurses. Rev Latino-Am Enfermagem[Internet]. 2014[cited 2017 Sep 3];22(5):724-30. Available from: http://www.scielo.br/pdf/rlae/ v22n5/0104-1169-rlae-22-05-00724.pdf

16. Luna WH, Bernardes JS. Tutorial groups as a strategy for meaningful learning among medical students. Rev Bras Educ Med[Internet]. 2016[cited 2017 Sep 3];40(4):653-62. Available from: http://www.scielo.br/pdf/rbem/v40n4/1981-5271-rbem-40-4-0653.pdf

17. Costa MCG, Tonhom SFR, Fleur LN. Teaching and learning professional practice: medical students' perspective. Rev Bras Educ Med[Internet]. 2016[cited 2018 Mar 27];40(2):245-53. Available from: http://www.scielo.br/pdf/rbem/v40n2/1981-5271rbem-40-2-0245.pdf

18. Middlewick Y, Kettle TJ, Wilson JJ. Curtains up! Using forum theatre to rehearse the art of communication in healthcare education. Nurse Educ Pract[Internet]. 2012[cited 2018 Mar 27];12(3):139-42. Available from: https://doi.org/10.1016/j.nepr.2011.10.010

19. Cogo ALP, Dal Pai D, Aliti GB, Hoefel HK, Azzolin KO, Busin L, et al. Case studies and role play: learning strategies in nursing. Rev Bras Enferm[Internet]. 2016[cited 2017 Sep 3];69(6):1163-7. Available from: http://www.scielo.br/pdf/reben/v69n6/en_00347167-reben-69-06-1231.pdf

20. Forehand JW, Leigh KH, Farrell RG, Spurlock AY. Social dynamics in group work. Teach Learn Nurs[Internet]. 2016[cited 2017 Dec 20];11(2):62-6. Available from: https://www.sciencedirect.com/science/article/pii/S1557308715000955

21. Leite KNS, Santos RS, Andrade SSC, Zaccara AAL, Costa TF. The internet and its influence in learning-teaching process of nursing students. Rev Enferm UERJ[Internet]. 2013[cited 2017 Dec 20];21(4):464-70. Available from: http://www.e-publicacoes.uerj.br/ index.php/enfermagemuerj/article/view/10006

22. Guedes GF, Ohara CVS, Silva GTR. Intensive care unit: a significant space for the professor-student relationship. Acta Paul Enferm[Internet]. 2012[cited 2017 Sep 3];25(2):146-50. Available from: http://www.scielo.br/pdf/ape/v25nspe2/23.pdf

23. Lima MM, Reibnitz KS, Kloh D, Vendruscolo C, Corrêa AB. Dialogue: network that intertwines the pedagogical relationship into the practical-reflective teaching. Rev Bras Enferm[Internet]. 2016[cited 2017 Dec 19];69(4):654-61. Available from: http://www. scielo.br/pdf/reben/v69n4/0034-7167-reben-69-04-0654.pdf 